\title{
Syncope and pneumomediastinum during the maxillary sinus elevation with an air-syringe: a case report
}

\author{
Su Wan Kim¹, Jonggeun Lee 1 , Ji-Young Song ${ }^{2 *}$ \\ 'Department of Thoracic and Cardiovascular Surgery, Jeju National Hospital, Jeju National School of Medicine, Jeju, Republic \\ of Korea \\ ${ }^{2}$ Department of Dentistry, Jeju National Hospital, Jeju National School of Medicine, Jeju, Republic of Korea
}

Pneumomediastinum is a very rare and potentially catastrophic complication of dental procedures. Its common causes are tooth extraction, endodontic treatment, and subgingival curettage using handpieces and high-pressure air/water syringes. We present a case of massive pneumomediastinum with subcutaneous emphysema in a 61-year-old female who underwent bone grafting into the maxilla for pretreatment of dental implantation using a syringe. The patient suffered from abrupt severe odynophagia and loss of consciousness. The patient transferred to emergency department and images work-up revealed a pneumomediastinum and subcutaneous emphysema on the entire face and neck. We performed conservative treatments including prophylactic antibiotics, oxygen inhalation, and fasting meals, and then discharge after 7 days uneventfully. The patient's syncope might be resulting from hypotension and pain shock induced by pneumomediastinum with a sudden chest compression. The pneumomediastinum could be resulting from concurrent perforation and massive air infiltration into the maxillary sinus during bone grafting. We suggest that pneumomediastinum needs prompt diagnosis and management because of the risk of airway obstruction when a patient present syncope in the dental room. (J Dent Rehabil Appl Sci 2021;37(3):171-6)

Key words: pneumomediastinum; emphysema; syncope; dental implantation

\begin{abstract}
서론
흉강(thoracic cavity)은 정상적으로 음압을 유지하기 때문에 공기는 목의 근막층을 따라서 종격동으로 침투하 기 쉽다. 깊은 층의 목근막은 여러 가지의 근막 공간으로 이루어지는데 이들 공간은 기관과 식도를 연결하여 공기 가 자유롭게 침투할 수 있는 직접적인 도관(conduit)을 형성한다. 이로 인해 비정상적으로 목과 종격동 안으로 공기가 유입되게 되면 이를 종격동기종(pneumomediastinum)이라 일컫는다. 종격동기종은 치과용 고속 핸드피 스나 air/water 주사기를 사용하여 치아의 발치, 삭제, 수

*Correspondence to: Ji-Young Song

Associate Professor, Department of Dentistry, School of Medicine, Jeju National University, 102 Jejudaehak-ro, Jeju-si, Jeju Special Self-Governing Province, 63243, Republic of Korea

Tel: +82-64-717-1840, Fax: +82-64-757-8276, E-mail: 2460song@naver.com

Received: July 12, 2021/Last Revision: August 5, 2021/Accepted: August 31, 2021
\end{abstract}

복 및 근관 치료, 치은 연하 소파술 등을 시행할 때 발생 할 수 있는 매우 드문 합병증으로 생명을 위협하는 심각 한 합병증이다. ${ }^{1}$

미주신경반사성 실신(syncope)은 치과 진료실에서 발 생하는 가장 흔한 내과적 응급상황이다. 이때는 환자를 바로 눕히고 환자를 관찰해야 하는데, 대부분의 환자는 기도가 확보되어 있고 호흡에 문제가 없으며, 적절한 맥 박을 가지고 있어 30 초에서 60 초 이내에 회복이 된다. 회 복이 늦어지는 경우에는 의식소실에 대해 적극적인 감별 진단이 요구된다. 치과에서 의식소실의 원인은 여러가지 가 있겠지만, 실신, 저혈당, 뇌경색, 심정지 등이 원인이

Copyright@ 2021 The Korean Academy of Stomatognathic Function and Occlusion. (c) It is identical to Creative Commons Non-Commercial License. 
될 수 있다. ${ }^{2}$

본 증례는 치과 진료 후 안와주위를 포함한 안면부 및 종격동에 발생한 기종과 실신이 동시에 발생한 극히 드 문 증례로 문헌고찰과 함께 보고하고자 한다

\section{증례 보고}

특이 병력이 없는 61세 여자 환자가 개인 치과 의원에 서 임플란트 시술 중 갑자기 의식을 잃어 본원 응급실로 전원되었다. 환자는 상악 좌측의 골이식 후 임플란트 수 술이 예정되어 있었고, 상악동 내 골이식을 위하여 주사
기로 입안에 공기를 넣다가 극심한 통증을 느낀 후 정신 을 잃었다고 하였다.

응급실 내원 당시 의식은 회복되었으나, 좌측 안구 주 위, 안면 부위 및 흥부에서 부종이 관찰되었고 얼굴과 목 을 만지면 비빔소리(crepitus)가 확인되었다. 구강 내 자 발적인 출혈은 없었으며 활력징후는 안정적이었다. 방사 선학적 검사 상 흥부 $\mathrm{X}$-선 사진과 경부 $\mathrm{X}$-선 사진에서는 대량의 피하기종(subcutaneous emphysema)이 주로 목 주위에서 관찰되었다(Fig. 1). 기관(trachea)을 따라서 공 기음영이 관찰되어 흉부 CT를 촬영하였으며, 종격동기 종(pneumomediastinum)이 진단되었다(Fig. 2).
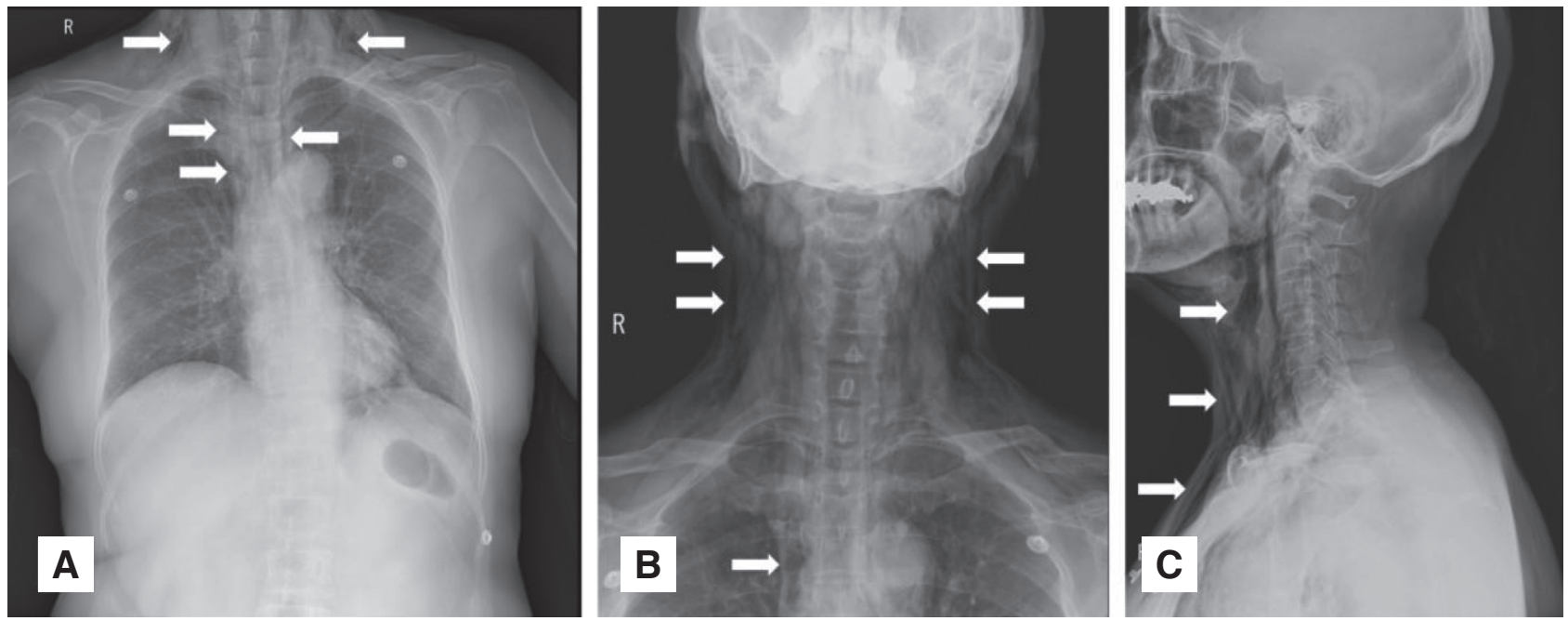

Fig. 1. A chest $x$-ray $(A)$ and cervical $x$-rays ( $B$ and $C$ ) show the large amount of subcutaneous emphysema. White arrows indicate subcutaneous emphysema and air densities in the mediastinum nearby the trachea.

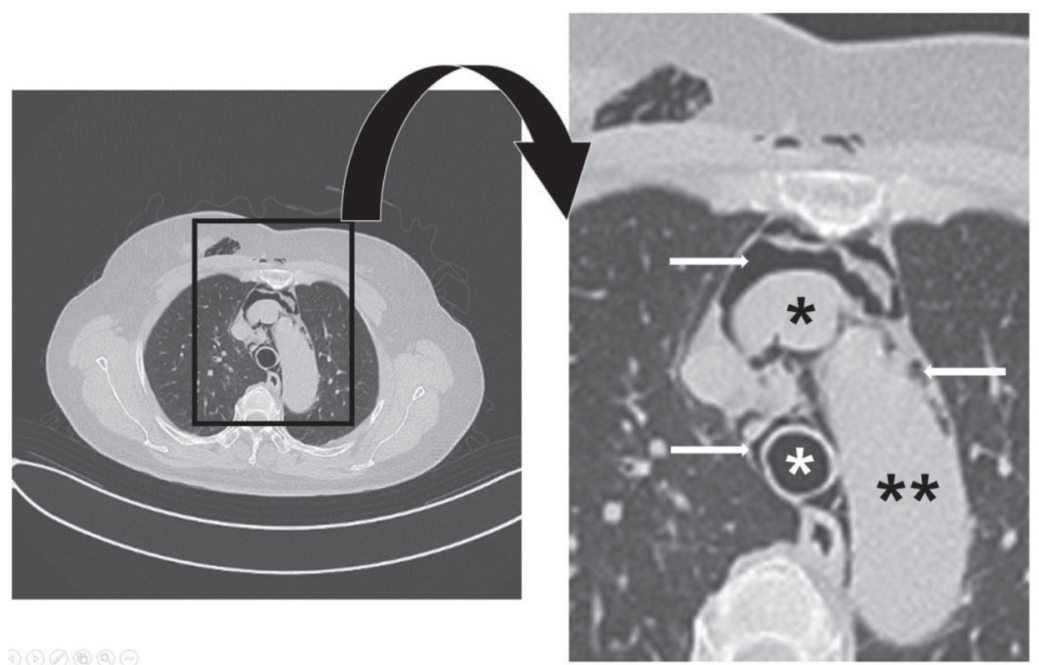

Fig. 2. Images of chest CT reveal the pneumomediastinum (white arrows). Mediastinal airs are encircling the innominate vein $(*)$, the aortic $\operatorname{arch}\left({ }^{*}\right)$, and the trachea (white star). 
환자는 치과 치료 시 $1: 100,000$ 에피네프린 함유 된 lidocaine $2 \mathrm{ml}, 1.5$ vial을 주입 받았고, 치과용 국소 마취 제의 혈관 유입에 의한 실신과 감별하기 위하여 심전도 촬영하였으나 부정맥은 관찰되지 않았다. 그 밖의 의식 소실의 원인을 찾기 위하여 두경부 CT를 촬영하였고 대 량의 기종이 피하조직뿐만 아니라 두경부 전체의 조직사 이에서 발견되었다(Fig. 3).

환자는 즉시 입원하여 예방적 항생제(cefazolin $1 \mathrm{~g}$ iv $\mathrm{q} 8 \mathrm{hrs})$ 와 산소 치료 $(4 \mathrm{~L} / \mathrm{min}$, nasal prong) 등 존적 치료 를 퇴원 전일까지 시행하였다. 자연 종격동기종(spontaneous pneumomediastinum)의 원인으로 추정되는 미세
한 식도 천공(pin-point esophageal perforation)의 가능 성 $^{3}$ 을 염려하여 금식을 유지하였고, 입원 5일째부터 식이 를 시작하고 7일째 퇴원하였다. 퇴원 당시 종격동 기종과 목 주위의 피하기종은 모두 소실되었다(Fig. 4).

\section{고찰}

종격동기종이란 종격동(mediastinum)에 공기 혹은 다 른 가스가 비정상적으로 존재하는 상태를 말한다. ${ }^{4}$ 대부 분의 원인은 외상에 의하며, 외상으로 인한 식도, 기관 및 기관지, 배, 목의 공기가 종격동에 들어가서 발생한다. 이
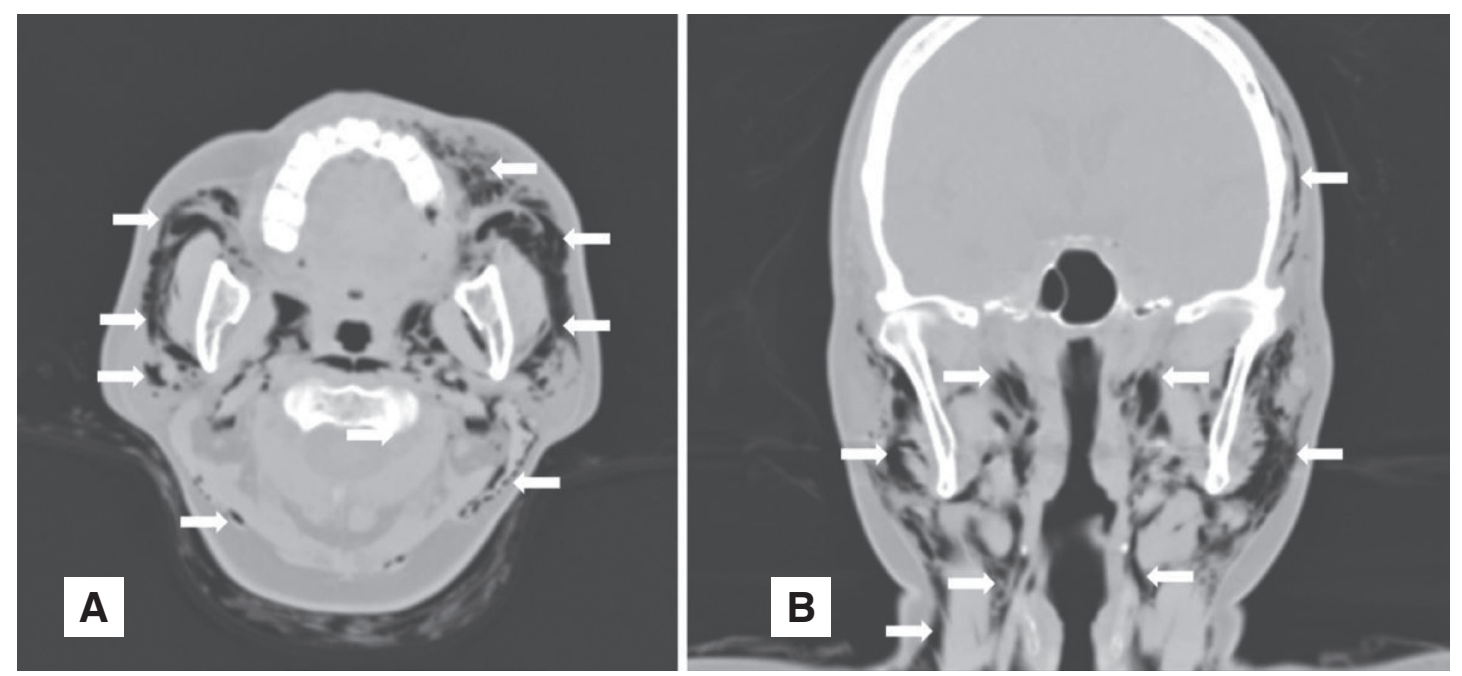

Fig. 3. Images of cranio-facial bone CT show massive air infiltrations into the entire tissues around the face and neck.
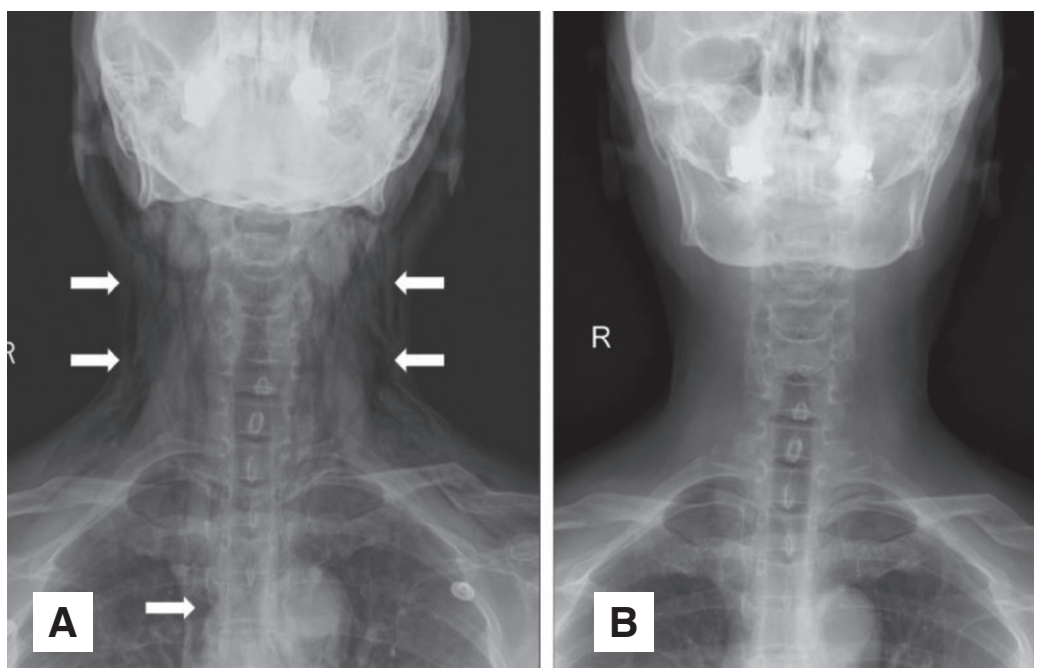

Fig. 4. Previously existing pneumomediastinum and subcutaneous emphysema (A) were disappeared at the day of discharge (B). 
환자의 경우는 치과 시술 시 사용한 air syringe에 의해 공 기가 상악동(maxillary sinus)을 통해 얼굴과 종격동으로 유입된 것으로 추측된다.

상악동거상술은 크게 측방접근법(lateral approach) 과 치조정접근법(crestral approach)으로 나눌 수 있다. ${ }^{5}$ Muronoi 등 ${ }^{6}$ 은 처음 balloon-assisted maxillary sinus floors augmentation을 제안하였고 이 당시에는 측방접 근법을 이용하여 상악동막을 분리시키는 방법을 사용하 였다. 2006년 Kfir 등은 이 술식을 좀 더 변형시켜 치조 정에 osteotomy site를 이용하여 풍선을 집어 넣은 후 부 풀리는 방법으로 상악동막을 분리하였고 이를 minimally invasive antral membrane balloon elevation (MIAMBE) 이라고 명칭하였다. 이 방법의 장점은 최소 침습으로 술 후 출혈, 부종, 환자의 통증이 적고 임플란트를 식립하고 자 하는 정확한 곳에 골이식을 할 수 있다는 것이다. 하 지만 풍선이 찢어질 수 있고, 술자에 따라 술기의 성공률 에서 차이가 크다. 최근에는 주사기에 물을 넣은 후 이 물의 수압(hydraulic pressure)을 이용하여 상악동막을 일차적으로 거상 후 풍선을 이용하여 추가적으로 상악동 막을 거상하는 술식도 보고되고 있다. 주사기의 수압을 이용하는 이 술식에서 가장 중요한 것은 상악동막이 찢 어진 경우 술자나 환자가 반드시 바로 알 수 있도록 주사 기에 반드시 물을 넣어야 한다는 것이다. 술식 도중 상악 동막이 찢어지는 경우 코로 물이 새거나 환자의 목구멍 뒤로 물이 넘어가는 것을 확인할 수 있다. ${ }^{8}$

이 환자의 경우 환자의 진술에 의거하면 “임플란트 식 립 전 위턱뼈에 구멍을 뜷은 후 그곳으로 주사기를 통해 2 - 3회 강력한 압력이 느껴지는 바람이 들어왔고, 그 이 후 즉각적인 극심한 통증으로 실신하였다.”고 하였다. 환 자의 실신 및 부종 이후 바로 응급실 내원하여 찍은 CT 상에서도 상악동의 air-fluid level이 관찰되지 않아 주사 기 내에 물을 넣지 않고 상악동을 거상 시키는 술식을 받 았을 확률이 높다. Osteotomy를 위한 drilling 시 찢어졌 거나 주사기를 통하여 전달된 과한 압력으로 상악동막이 찢어지게 되고, 이를 인지 하지 못한 상태에서 지속적으 로 상악동 내로 주사기를 이용하여 공기를 주입 한 것이 본 증례의 피하기종 및 종격동기종의 원인이 되었을 것이 라 추측한다.

상기 환자의 의식소실(syncope)은 종격동기종이 발생 하면서 일시적이고 강한 흉부 압박으로 인해 혈압 감소 와 통증 속(pain shock)에 의한 것으로 생각되며, 호흡곤 란으로 인한 의식 소실도 의심해 볼 수 있다. ${ }^{9}$ 종격동기종
과 관련하여 의식소실을 일으킬 수 있는 경우는 경막외 기종(pneumorrhachis)이 발생한 경우인데, 경막외기종 이란 척수를 둘러싼 경막부위에 공기누출이 발생하는 질 환이다. 주로 외상, 척추 천자, 경막외 농양, 디스크의 이 탈 등에서 발생하게 된다. ${ }^{10}$ 이 환자에서는 목과 안면부 에 대량의 기종이 있었으나 경막외기종은 발견되지 않아, 이로 인한 의식소실은 아니었음을 감별하였다.

종격동기종의 원인으로 자연성(spontaneous)이 있으 며 그 기전은 정확치 않으나, 임상적으로 외부요인 없이 젊은 연령에서 격렬한 운동, 자발성 기침, 심한 구토 등 에 의해 갑자기 흥곽 내압 및 복압 상승으로 폐내의 소기 포(bleb)가 파열되어 간질성 폐기종(interstitial emphysema)을 만들고, 이 공기가 종격동으로 들어가는 것으로 추정된다. ${ }^{4}$

임상 양상으로는 흥골 뒤쪽의 통증과 흉벽, 목에서 들 리는 염발음(crepitation)이 주된 소견이며, 기흥(pneumothorax)과 동반될 때가 종종 있다. 통증은 호흡, 기침, 몸의 위치 및 연하 시 통증의 증가 또는 악확되기도 하며, 목, 양측 어깨 및 윗팔 등으로 방사되는 통증을 호소할 수 있다. 종격동내의 공기가 혈관을 압박해서 호흡곤란 이 발생할 수도 있다. ${ }^{9}$

종격동기종과 동시에 경부 피하 기종이 관찰되는 경우 나 구토 후에 생기는 종격동기종의 경우에는 기도, 기관 지 혹은 식도 파열 가능성을 의심하여야 한다. 이 때는 철 저한 임상 증상, 현병력 및 과거력의 심층관찰과 식도조 영술 혹은 기관지 내시경 검사를 시행하여야 한다. ${ }^{3,11,12}$ 이 환자에서는 비교적 원인이 명확하여 다른 침습적 검사 는 시행하지 않았고, 혹시 모를 기도와 식도천공의 우려 로 예방적 항생제 및 금식을 유지하였다.

외상에 의한 종격동기종의 치료는 그 외상을 치료하는 것이고, 경우에 따라 종격동기종 자체에 대해 산소치료 나 안정요법을 시행할 수도 있으나 외과적 감압술이 필 요한 경우는 거의 없다. 진통제, 진해제, 안정제, 항생제 등의 보존적 치료와 안정 가료를 하면, 자연성 종격동기 종은 대부분 후유증 없이 자연 소실된다..$^{13,14}$ 종격동기종 자체가 종격동염(mediastinitis)을 일으키는 사례는 문헌 을 통해 보고된 바가 없다.

\section{결론}

치과 분야에서 의인성으로 발생하는 종격동기종은 매 우 드문 합병증으로 거의 보고된 적이 없다. 종격동기종 
이 발생하더라도 즉각적인 산소치료, 안정가료, 항생제, 금식 등의 보존적 치료만으로도 좋은 경과를 보이며 종 격동염과 같은 심각한 합병증으로 진행될 가능성은 매우 희박하다. 따라서 임상진료 시 이러한 상황이 발생하는 경우 지체 없이 응급실로 환자를 이송하여 정확한 진단 및 처치를 할 수 있어야 하겠다.

\section{Acknowledgements}

이 논문은 2021학년도 제주대학교 교육-연구 및 학생 지도비 지원에 의해서 연구되었음.

\section{ORCID}

Su Wan Kim https://orcid.org/0000-0002-6531-7266

Jonggeun Lee https://orcid.org/0000-0003-3797-8582

Ji-Young Song https://orcid.org/0000-0002-9500-6557

\section{References}

1. Rawlinson RD, Negmadjanov U, Rubay D, Ohanisian L, Waxman J. Pneumomediastinum After Dental Filling: A Rare Case Presentation. Cureus 2019;11: e5593.

2. Reed KL. Basic management of medical emergencies: recognizing a patient's distress. J Am Dent Assoc 2010;141 Suppl 1:20S-4S.

3. Grapatsas K, Tsilogianni Z, Leivaditis V, Kotoulas S, Kotoulas C, Koletsis E, Iliadis IS, Dahm M, Trakada G, Veletza L, Kallianos A, Huang H, Kosmidis C, Karanikas M, Thomaidis V, Porpodis K, Zarogoulidis P. Hamman's syndrome (spontaneous pneumomediastinum presenting as subcutaneous emphysema): A rare case of the emergency department and review of the literature. Respir Med Case Rep 2017;23:63-5.

4. Rose WD, Veach JS, Tehranzdeh J. Spontaneous pneumomediastinum as a cause of neck pain, dysphagia, and chest pain. Arch Intern Med 1984;144: 392-3.

5. Starch-Jensen T, Jensen JD. Maxillary Sinus Floor Augmentation: a Review of Selected Treatment Modalities. J Oral Maxillofac Res 2017;8:e3.

6. Muronoi M, Xu H, Shimizu Y, Ooya K. Simplified procedure for augmentation of the sinus floor using a haemostatic nasal balloon. Br J Oral Maxillofac Surg 2003;41:120-1.

7. Kfir E, Kfir V, Mijiritsky E, Rafaeloff R, Kaluski E. Minimally invasive antral membrane balloon elevation followed by maxillary bone augmentation and implant fixation. J Oral Implantol 2006;32:26-33.

8. Hussein LA, Hassan TAL. The Effectiveness of Oxidized Regenerated Cellulose as a Graft Material in Transalveolar Osteotome Sinus Lift Procedure. J Craniofac Surg 2017;28:1766-71.

9. Abolnik I, Lossos IS, Breuer R. Spontaneous pneumomediastinum. A report of 25 cases. Chest 1991; 100:93-5.

10. Goh BK, Yeo AW. Traumatic pneumorrhachis. J Trauma 2005;58:875-9.

11. Caceres M, Ali SZ, Braud R, Weiman D, Garrett HE Jr. Spontaneous pneumomediastinum: a comparative study and review of the literature. Ann Thorac Surg 2008;86:962-6.

12. Sahni S, Verma S, Grullon J, Esquire A, Patel P, Talwar A. Spontaneous pneumomediastinum: time for consensus. N Am J Med Sci 2013;5:460-4.

13. Maunder RJ, Pierson DJ, Hudson LD. Subcutaneous and mediastinal emphysema. Pathophysiology, diagnosis, and management. Arch Intern Med 1984; 144:1447-53.

14. Feldtman RW, Oram-Smith JC, Manning LG, Buckley CJ. Spontaneous mediastinal emphysema. J Pediatr Surg 1980;15:648-50. 


\section{주사기를 이용한 상악동 거상술 시 발생한 실신 및 종격동기종에 관한 증례보고}

김수완 ${ }^{1}$ 부교수, 이종근 ${ }^{1}$ 조교수, 송지영 ${ }^{2 *}$ 부교수

${ }^{1}$ 제주대학교 의과대학 흥부외과학교실

${ }^{2}$ 제주대학교 의과대학 치과학교실

종격동기종은 치과 영역에서 매우 드물고 잠재적으로 위험한 합병증이다. 이의 흔한 원인으로는 핸드피스와 고압 공기/ 물 주사기를 사용하는 발치, 근관치료, 잇몸 밑 치은연하 소파술 등이 있다. 본 증례는 임플란트 식립을 위한 전 치료로 주사기를 이용하여 상악동에 골이식을 시행받은 61세 여자에게서 발생한 대량의 종격동기종과 피하기종의 증례이다. 환 자는 치료 도중 갑작스럽게 발생한 구강 통증과 함께 의식 소실이 발생하였고, 응급실로 전원 되었다. 영상학적 검사상 종격동기종과 함께 얼굴과 목부위 전체에 피하기종이 발견되었다. 예방적 항생제, 산소 흡입, 금식 등의 보존적 치료가 이루어졌고, 합병증 없이 7일 만에 퇴원하였다. 환자의 실신은 시술 중 상악동 천공 후 과량의 공기유입으로 인해 발생한 종격동기종에 의해 순간적인 강한 흉부 압박으로 혈압 감소와 통증 쇽에 의한 것으로 생각된다. 치과 치료 중 환자가 의 식을 잃었다면 기도 폐쇄의 위험성이 있기 때문에 종격동기종을 즉각적으로 감별하고 치료해야 한다.

(구강회복응용과학지 2021;37(3):171-6)

주요어: 종격동기종; 기종; 실신; 치아 임플란트 